\title{
Effects of the aged garlic extract on spinal cord injury model in rat
}

\section{Sıçan omurilik yaralanma modelinde dinlenmiş sarımsak özütünün etkileri}

\author{
Berker CEMIL, ${ }^{1}$ Emre Cemal GÖKCE, ${ }^{1}$ Hüsamettin ERDAMAR, ${ }^{2}$ Ayça KARABÖRK, ${ }^{3}$ \\ Özlem ONUR, ${ }^{4}$ Aylin HEPER OKCU, ${ }^{3}$ Ramazan YİĞITTOGLU, ${ }^{2}$ Bülent ERDOĞAN ${ }^{1}$
}

\section{BACKGROUND}

Aged garlic extract (AGE) is a potent antioxidant agent with an established neuroprotective effect in cerebral ischemia. However, the potential protective effect of AGE in spinal cord injury (SCI) is still unknown.

\section{METHODS}

Spinal cord trauma was applied to 19 adult male Wistar rats using the clip compression method. Animals were divided into three groups. Animals in the AGE group were administered $250 \mathrm{mg} / \mathrm{kg}$ per day of AGE diluted in tap water orally by gavage for 15 days prior to trauma. After spinal cord trauma, malondialdehyde (MDA) and superoxide dismutase (SOD) levels of the AGE group were compared with the animals in the control and SCI groups. The animals were examined by inclined plane 24 hours (h) after the trauma. At the end of the experiment, spinal cord tissue samples were harvested for pathological evaluation.

\section{RESULTS}

Regarding tissue MDA and SOD levels after trauma, animals in the AGE group demonstrated decreased MDA levels and increased SOD levels when compared with the SCI group. However, these results were no better than in the control group. The AGE group demonstrated better pathological findings than the SCI group. The result regarding the functional finding was similar.

\section{CONCLUSION}

AGE demonstrated neuroprotective effects in SCI. Further studies with different experimental settings are required to achieve conclusive results.

Key Words: Aged garlic extract; antioxidant enzymes; lipid peroxidation; spinal cord injury.

\section{$\boldsymbol{A M A C}$}

Dinlenmiş sarımsak özütü (aged garlic extract - AGE) serebral iskemide nöroprotektif etkileri gösterilmiş güçlü bir antioksidan ajandır. Ancak AGE'nin omurilik yaralanmasinda potansiyel koruyucu etkileri halen bilinmemektedir.

\section{GEREÇ VE YÖNTEM}

Wistar cinsi 19 yetişkin erkek sıçana klip kompresyon metodu ile omurilik travması uyguland. Hayvanlar üç gruba ayrıldı. Travmadan 15 gün once sıçanlara gavajla oral yolla $250 \mathrm{mg} / \mathrm{kg}$ 'a AGE suda çözülerek verildi. Omurilik yaralanması sonrası AGE verilen gruptaki sıçanların malondialdehit (MDA) ve süperoksitit dismutaz (SOD) seviyeleri, kontrol grubundaki ve sadece omurilik travması uygulanan gruptaki sıçanlarla karşılaştırıldı. Hayvanlar travma sonras1 24. saatte eğik düzlemde değerlendirildi. Deney sonrası omurilik doku örnekleri patolojik incelemeye gönderildi.

\section{BULGULAR}

Dokulardaki MDA ve SOD seviyeleri incelendiğinde, AGE verilmiş ve omurilik travması uygulanmış gruptaki sıçanlarda, sadece omurilik travması uygulanmış sıçanlara göre azalmış MDA ve artmış SOD seviyeleri saptandı. Bununla birlikte sonuçlar kontrol grubundakilere göre daha iyi değildi. AGE grubun patolojik bulguları omurilik yaralanması grubuna göre daha iyiydi. Aynı zamanda fonksiyonel değerlendirme bulguları benzer sonuçlar gösteriyordu.

\section{SONUÇ}

AGE, omurilik yaralanmasında koruyucu etkiler göstermiştir. AGE’nin etkinliği ile ilgili daha ileri ve farklı deneysel çalışmalara ihtiyaç duyulmaktadır.

Anahtar Sözcükler: Dinlenmiş sarımsak özütü; antioksidan enzimler; lipit peroksidasyon; spinal kord yaralanmas1.
Departments of ${ }^{1}$ Neurosurgery, ${ }^{2}$ Biochemistry, ${ }^{4}$ Physical Medicine and Rehabilitation, Fatih University Faculty of Medicine, Ankara;

${ }^{3}$ Department of Pathology, Ankara University Faculty of Medicine, Ankara, Turkey.
Fatih Üniversitesi Tıp Fakültesi, ${ }^{1}$ Beyin ve Sinir Cerrahisi Anabilim Dalı, ${ }^{2}$ Biyokimya Anabilim Dal,,${ }^{4}$ Fizik Tedavi ve Rehabilitasyon Anabilim Dalı, Ankara; ${ }^{3}$ Ankara Üniversitesi Tıp Fakültesi, Patoloji Anabilim Dalı, Ankara. 
Spinal cord trauma results in devastating neurological impairment and disabilities. Neuronal fiber damage, mass ischemic neural cell necrosis and apoptosis, metabolic disturbances, destruction of microvasculature, inflammation, lipid peroxidation, free radical production, demyelination, and glial scar formation are the pathological mechanisms occurring following spinal cord trauma, leading to extensive secondary tissue injuries. ${ }^{[1,2]}$ Even though mechanical destruction of the nerve axons in the spinal cord is not amenable to therapy, changes in secondary injury are prone to therapeutic intervention. ${ }^{[3]}$

Garlic (Allium sativum) is a common food spice consumed worldwide as a food flavoring agent and as a traditional medicine to enhance physical and mental health. ${ }^{[4]}$ There are several reports providing the pharmacological evidences for its antiatherogenic, antiatherosclerotic, hypoglycemic, hypolipidemic, antioxidant, antimicrobial, and antitumor properties. ${ }^{[5-7]}$

To our knowledge, following a review of the English literature, the effect of aged garlic extract (AGE) after spinal cord injury (SCI) has not been evaluated biochemically, pathologically, or functionally. In this study, we investigated the effects of AGE on the levels of malondialdehyde (MDA) and superoxide dismutase (SOD) biochemically, on the light microscope, pathologically, and based on early functional results using an experimental SCI rat model.

\section{MATERIALS AND METHODS}

\section{Experimental groups}

The Experimental Animal Committee at Fatih University School of Medicine approved this work, and the National Institute of Health's Guide for the Care and Use of Laboratory Animals was followed. Nineteen male adult Wistar rats weighing 250-300 g were included in the study. All rats were anesthetized intraperitoneally with $10 \mathrm{mg} \cdot \mathrm{kg}^{-1}$ xylazine (Rompun, Bayer, Istanbul, Turkey) and $50 \mathrm{mg} \cdot \mathrm{kg}^{-1}$ ketamine hydrochloride (Ketalar, Pfizer, Istanbul, Turkey).

The rats were divided into three groups:

A) Group I ( $\mathrm{n}=5)$ (Control group): Laminectomy was performed.

B) Group II ( $\mathrm{n}=7$ ) (SCI group): The animals underwent traumatic SCI after laminectomy. Trauma was performed by using 70-g closing force aneurysm clip (Yasargil FE 721, Aesculap, Istanbul, Turkey), which was applied onto the spinal cord, T7 level, for 1 minute $(\mathrm{min}) .^{[8]}$

C) Group III (n=7) (AGE group): All rats were given $250 \mathrm{mg} \mathrm{kg}-1$ per day of AGE diluted in tap water orally by gavage for 15 days prior to the trauma. A commercially available AGE (KYOLIC ${ }^{\circledR}$ ) was kindly provided by Wakunaga of America (Mission Viejo, CA). ${ }^{[9]}$

Following the application of anesthetic agents, the rats were placed on the operating table in the prone position. The skin was incised in the midline of the T5-T8 region after local area disinfection. The paravertebral muscles were dissected subperiosteally. Laminectomy was done at T6 and T7. Bleeding control was done with bipolar coagulator. The dura mater was left intact. Following trauma, paraplegia was identified in all subjects using painful stimulus to the tail. Following the usage of the clip, the animals were kept alive for 24 hours (h) under appropriate conditions and veterinary control, after which decapitation took place after anesthetization using the same anesthetic agents. Spinal cord samples $(15 \mathrm{~mm})$ were obtained from the operated spinal cord area and divided into two equal parts; then, the animals were sacrificed. Cranial parts of the tissue samples were obtained for microscopy evaluation; caudal parts were cleaned of blood with a scalpel and immediately stored in a $-20^{\circ} \mathrm{C}$ freezer for biochemical analysis.

\section{Biochemical analysis}

\section{Preparation of tissue samples}

Tissues were homogenized in four volumes of icecold Tris- $\mathrm{HCl}$ buffer $(50 \mathrm{mM}, \mathrm{pH} 7.4)$ using a homogenizer (Ultra Turrax IKA T18 Basic homogenizer, Germany) for 2 min at $5000 \mathrm{rpm}$, after cutting the organs into small pieces. MDA level was determined in this homogenate. Some of the homogenate was also centrifuged and its supernatant was separated. The supernatant solution was extracted with an equal volume of an ethanol/chloroform mixture (5/3, volume per volume $[\mathrm{v} / \mathrm{v}])$. After centrifugation at $5000 \times \mathrm{g}$ for $30 \mathrm{~min}$, the upper layer (ethanol phase) was used in the SOD activity and protein assays. All preparation procedures were performed at $+4^{\circ} \mathrm{C}$.

\section{MDA determination}

The tissue MDA levels were determined by the method of Draper and Hadley based on the reaction of MDA with thiobarbituric acid (TBA) at $95^{\circ} \mathrm{C} \cdot{ }^{[10]} \mathrm{In}$ the TBA test reaction, MDA and TBA react to form a pink pigment with an absorption maximum at $532 \mathrm{~nm}$. The reaction was performed at $\mathrm{Ph} 2-3$ at $95^{\circ} \mathrm{C}$ for 15 min. The sample was mixed with 2.5 volumes of $10 \%$ $(\mathrm{w} / \mathrm{v})$ trichloroacetic acid to precipitate the protein. The precipitate was pelleted by centrifugation and the supernatant was reacted with $0.67 \%$ TBA in a boiling waterbath for $15 \mathrm{~min}$. After cooling, the absorbance was read at $532 \mathrm{~nm}$ (Shimadzu UV-1601, Japan). Arbitrary values obtained were compared with a series of standard solutions (1,1,3,3- tetramethoxypropane). Results were expressed as nmol/mg tissue. 


\section{SOD activity determination}

Total $(\mathrm{Cu}-\mathrm{Zn}$ and $\mathrm{Mn})$ SOD (EC 1.15.1.1) activity was determined according to the method of Sun et al. ${ }^{[11]}$ The principle of the method is based on the inhibition of nitro-blue tetrazolium (NBT) reduction by the xanthine-xanthine oxidase system as a superoxide generator. Activity was assessed in the ethanol phase of the lysate after $1.0 \mathrm{ml}$ ethanol/chloroform mixture $(5 / 3, v / v)$ was added to the same volume of sample and centrifuged. One unit of SOD was defined as the enzyme amount causing 50\% inhibition in the NBT reduction rate. SOD activity was expressed as units per mg protein.

\section{Pathological investigation}

The specimen was immersed into $10 \%$ buffered formalin and stored at $4{ }^{\circ} \mathrm{C}$. One week after the sampling, they were removed from the store and placed in fresh fixative. Fixed tissue samples were processed routinely by paraffin embedding technique. Sections of $5 \mu \mathrm{m}$ were obtained on the coronal plane and stained with hematoxylin-eosin. The preparations were evaluated using a light microscope. All the sections were evaluated morphologically by the same pathologist who was blinded to the treatment groups for presence of congestion, edema, axonal degeneration, and necrosis. All these parameters were calculated in terms of the percentage of the damaged surface, and the classification used was as follows: 0 (no damage), 1 (slight) $\leq 5 \%, 2$ (minimal) 6-20\%, 3 (moderate) $21-50 \%, 4$ (severe) $51-75 \%$, and 5 (very severe) $76-100 \%$. $^{[12]}$

\section{Functional evaluation}

Functional evaluation of the animals was made 24

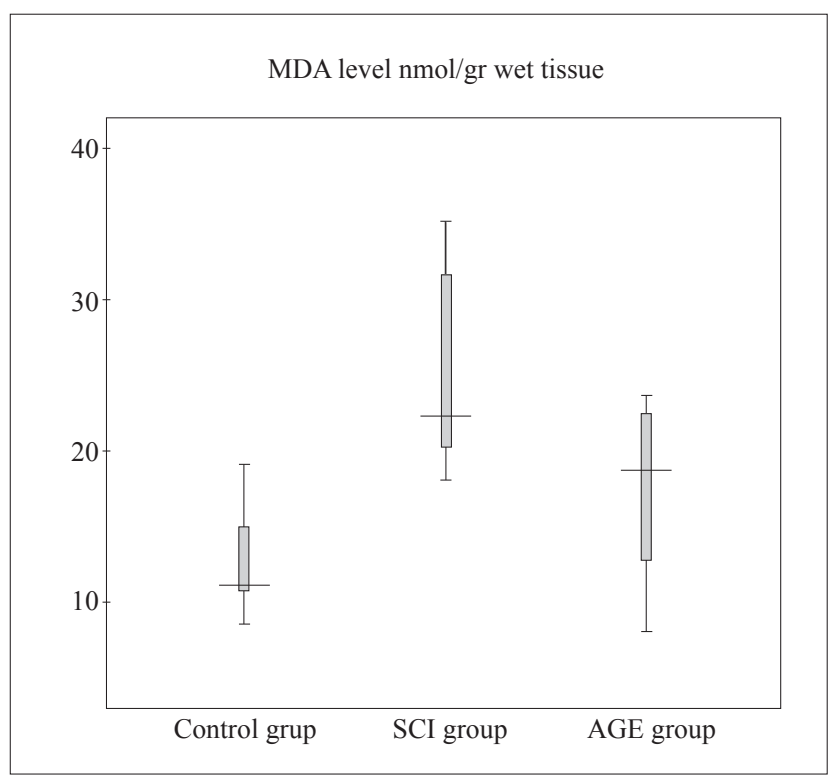

Fig. 1. Box and whisker plots showing MDA level differences among groups. $\mathrm{h}$ after the trauma. The motor function of the rats was assessed in a blind manner by the inclined plane (IP) technique of Rivlin and Tator. ${ }^{[13]}$ Rivlin and Tator's technique was used to evaluate the maximum sloping, during which rats maintain themselves for 5 seconds (s), using the IP test.

\section{Statistical analysis}

The Statistical Package for the Social Sciences 16.0 software (SPSS, Chicago, IL, USA) was used for statistical calculations and graphs. The results were expressed as mean \pm SD. Statistical comparisons between the groups were tested with the Kruskal-Wallis test, and the Mann-Whitney U-test was used for dual comparisons. Values of $\mathrm{p}<0.05$ were considered statistically significant.

\section{RESULTS}

\section{Biochemical analysis}

\section{Activity of $M D A$}

The mean plasma MDA level was $12.89 \pm 4.19$ $\mathrm{nmol} / \mathrm{g}$ wet tissue in the control group, and induction of spinal cord trauma increased this level to $27.01 \pm 6.75 \mathrm{nmol} / \mathrm{g}$ wet tissue in the SCI group. A statistically significant difference was found among all groups $(p<0.05)$. AGE feeding resulted in a decrease $(16.07 \pm 6.6 \mathrm{nmol} / \mathrm{g}$ wet tissue), but there was no statistically significant difference between the control group and AGE group. A comparison of the control and SCI groups demonstrated no significant difference $(p>0.05)$. However, a statistically significant difference was found between the SCI and AGE groups $(p<0.05)$ (Fig. 1).

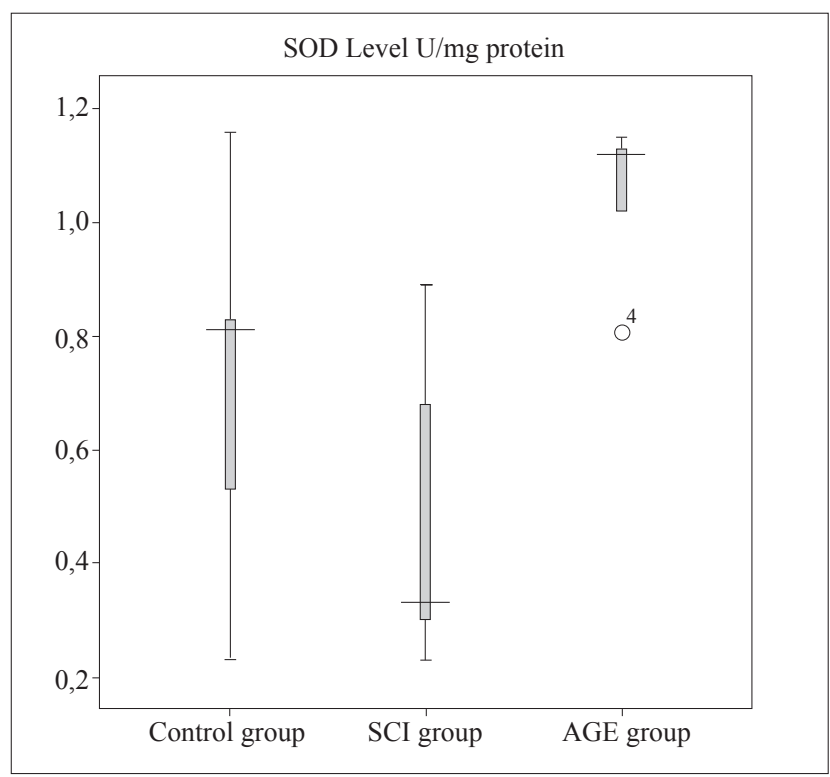

Fig. 2. Box and whisker plots showing SOD level differences among groups. 


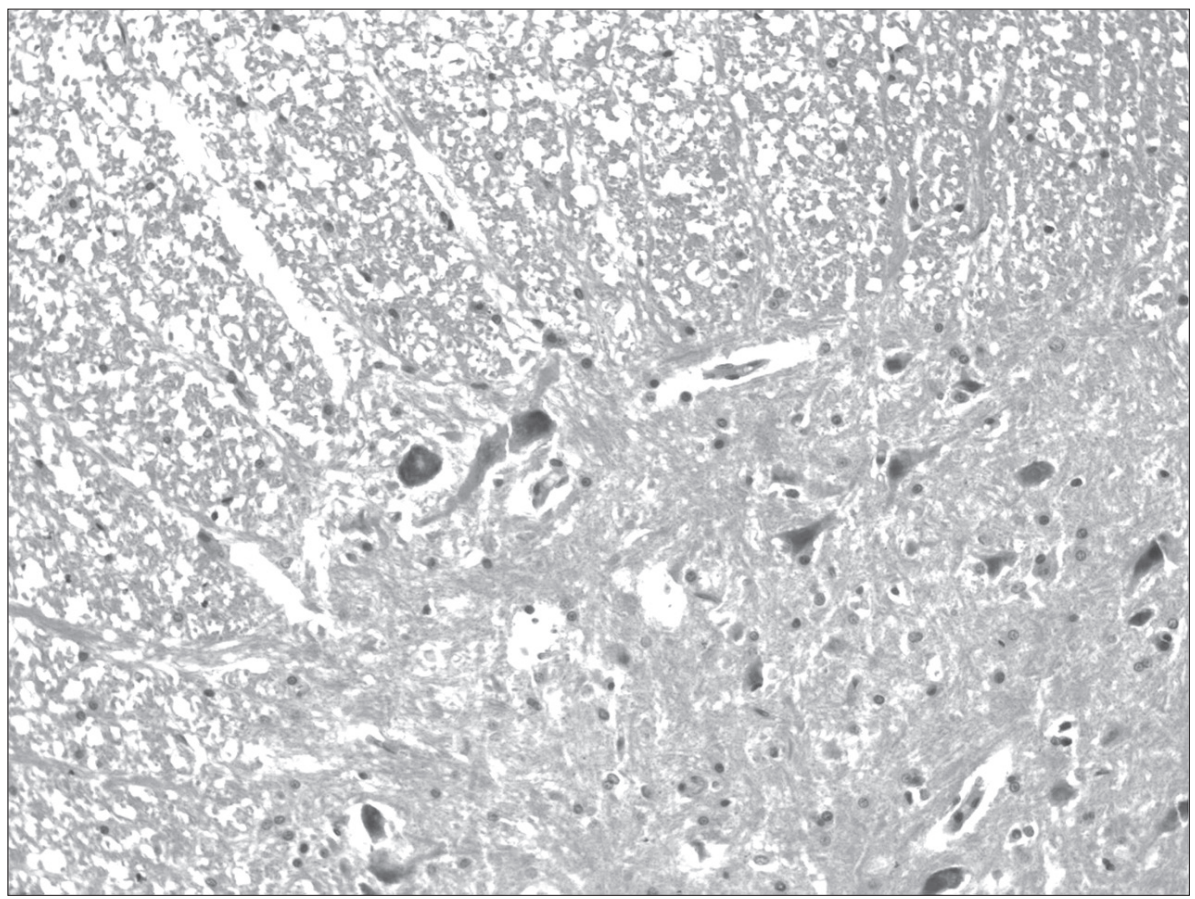

Fig. 3. Pathological section of spinal cord from the trauma group rat demonstrating severe degeneration, edema, and congestion (H-E x 200).

\section{Activity of SOD}

The mean plasma SOD level was $0.71 \pm 0.35 \mathrm{U} / \mathrm{mg}$ protein in the control group, and induction of spinal cord trauma decreased this level to $0.48 \pm 0.23 \mathrm{U} / \mathrm{mg}$ protein in the SCI group. A statistically significant difference was found among all groups $(p<0.05)$. AGE feeding resulted in an increase $(0.95 \pm 0.2 \mathrm{U} / \mathrm{mg}$ protein), but there was no statistically significant difference between the control group and AGE group. A comparison of the control and SCI groups demonstrated no significant difference $(\mathrm{p}>0.05)$. However, a statistically significant difference was found between the SCI and AGE groups $(\mathrm{p}<0.05)$ (Fig. 2).

\section{Light microscopy findings}

Pathological data are summarized in Table 1.

Necrosis was found to be significantly different between all groups $(p<0.05)$. In addition, a statistically significant difference was found between the SCI and AGE groups $(\mathrm{p}<0.05)$. However, no difference was found between the control and AGE groups ( $p>0.05)$.

Very severe degeneration was observed in the SCI group (Fig. 3). Necrosis was found to be significantly different between all groups $(p<0.05)$. Between the control and AGE groups, no statistically significant difference was found $(\mathrm{p}>0.05)$. In addition, no difference was found between the SCI and AGE groups $(\mathrm{p}>0.05)$.

Edema was less severe in the control and AGE groups (Fig. 4). Edema was found to be significantly different among all groups $(\mathrm{p}<0.05)$. A statistically significant difference was found between the control and AGE groups $(\mathrm{p}<0.05)$. No difference was found between the SCI and AGE groups $(\mathrm{p}>0.05)$.

Congestion was minimal in the control group. Edema was not found to be significantly different among all groups $(\mathrm{p}>0.05)$.

\section{Functional findings}

Statistically significant differences were found in the mean IP scores among all groups $(p<0.05)$. The SCI group showed a statistically significant decrease compared with the control group $(\mathrm{p}<0.05)$. No statistically significant differences were found between the values of the control and AGE groups ( $p>0.05)$. There was also no statistically significant difference between

Table 1. Values of pathological parameters $($ mean \pm SD)

\begin{tabular}{lcccc}
\hline Groups & Necrosis & Degeneration & Edema & Congestion \\
\hline Control group & $0.009 \pm 0.008$ & $0.07 \pm 0.09$ & $0.006 \pm 0.005$ & $0.128 \pm 0.085$ \\
Trauma group & $0.574 \pm 0.209$ & $0.396 \pm 0.2814$ & $0.351 \pm 0.355$ & $0.328 \pm 0.263$ \\
Trauma+Aged garlic extract group & $0.216 \pm 0.265$ & $0.188 \pm 0.235$ & $0.247 \pm 0.126$ & $0.231 \pm 0.224$ \\
\hline
\end{tabular}




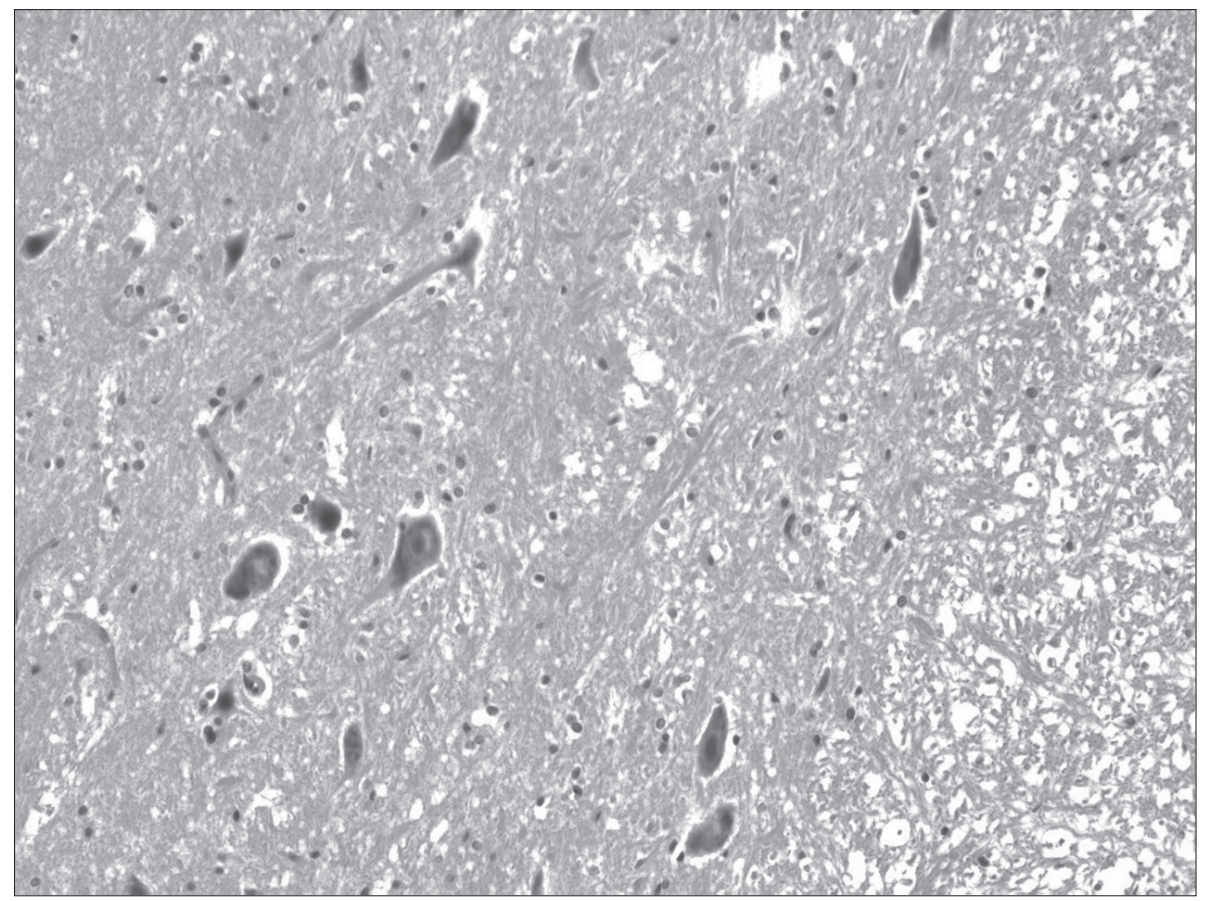

Fig. 4. Pathological section of spinal cord from the AGE group rat demonstrating reduced degeneration, edema, and congestion (H-E x 200).

the values of the SCI and AGE groups ( $\mathrm{p}>0.05)$ (Fig. $5)$.

\section{DISCUSSION}

Trauma-induced primary lesion of the spinal cord is an irreversible process. Only the secondary damage processes may be attenuated using neuroprotective treatments. ${ }^{[14]}$ Following the primary lesion of the spinal cord, edema, ischemia, calcium overload, lipid peroxidation, and microcirculation obstruction occur at the injured location. ${ }^{[15]}$

Lipid has composed the main structure of the central nervous system. It renders the neuronal tissues prone to hydroxyl radicals or lipid peroxidation. ${ }^{[16]}$ Lipid peroxidation increases spinal cord hypoperfusi-

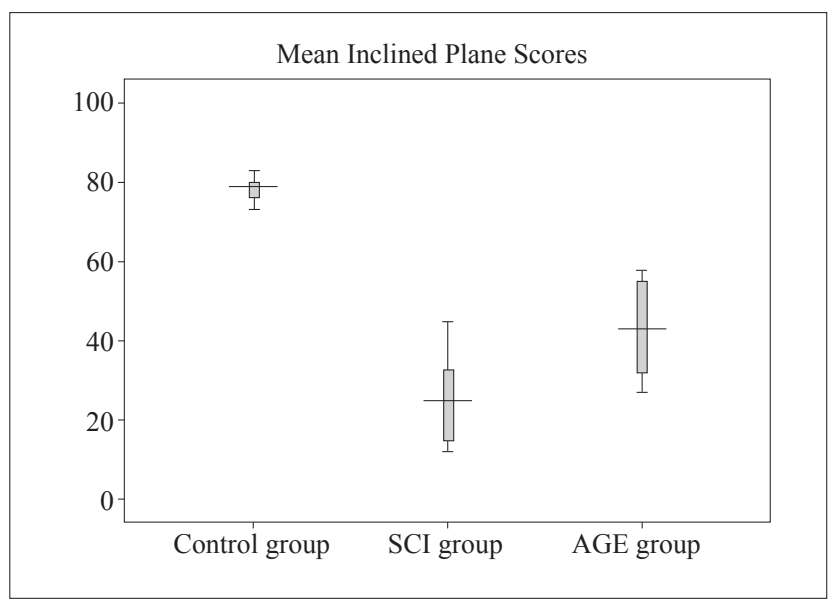

Fig. 5. Box and whisker plots showing mean inclined plane score differences among groups. on, edema formation, axonal conduction failure, and breakdown of energy metabolism. ${ }^{[17]}$ MDA is formed from the breakdown of polyunsaturated fatty acids and serves as an important and reliable marker for determining the extent of the peroxidation reaction. ${ }^{[18]}$ Metabolic bursts, in which oxygen is reduced to superoxide $\left(\mathrm{O}_{2}\right)$, hydrogen peroxide $\left(\mathrm{H}_{2} \mathrm{O}_{2}\right)$, and hydroxyl radical, can be elicited by various stimuli. SOD eliminates superoxides by converting them to $\mathrm{H}_{2} \mathrm{O}_{2} \cdot{ }^{[8]} \mathrm{H}_{2} \mathrm{O}_{2}$ is reduced to water by cytosolic antioxidants, catalase (CAT), and glutathione peroxidase (GSH-Px). ${ }^{[19]}$

The medicinal uses of garlic (Allium sativum) have a long history ${ }^{[20]}$ Drawings and carvings of garlic were uncovered in Egyptian tombs, dating from 3700 BC. Its uses as a remedy for heart disease, tumors and headaches are documented in the Egyptian Codex Ebers, dating from $1550 \mathrm{BC} \cdot{ }^{[21]} \mathrm{AGE}$ is an odorless product resulting from prolonged extraction of fresh garlic at room temperature; it is highly bioavailable and has biological activity in vitro in both animals and humans. ${ }^{[22]}$ The major unique organosulfur compounds in AGE are water-soluble S-allylcysteine and S-allylmercaptocysteine, which have potent antioxidant activity. ${ }^{[23]}$ Lipid-soluble compounds in AGE include diallyl sulfide, triallyl sulfide, diallyl disulfide, diallyl polysulfides, and others. ${ }^{[2]}$ The lipid-soluble organosulfur compounds show antioxidant effects. ${ }^{[25]}$ Little is known about the mechanisms involved in AGE-mediated protection, mainly due to garlic's complex chemical composition. However, evidence suggests that garlic's antioxidant properties may be involved in neuronal injury. ${ }^{[26]}$ In the present study, the 
mean IP score of the AGE group was better than of the trauma group. In addition, the tissue level of SOD was significantly increased in the AGE group. It has also been shown that AGE treatment significantly decreases the MDA level in the spinal cord. When the pathological sections were analyzed, it was shown that traumatic SCI caused necrosis, degeneration, edema, and congestion. AGE treatment showed marked reduction of these pathological features of trauma.

To our knowledge, based on the available published literature, AGE has not been used as a neuroprotective agent after SCI. In our study, AGE showed neuroprotective effects on the biochemical analysis after spinal cord trauma. These results were compatible with the findings of the studies by Aguilera. ${ }^{[27]}$ They reported that the neuroprotective effect of AGE in a cerebral ischemia model might be associated with control of the free-radical burst induced by reperfusion, preservation of antioxidant enzyme activity, and the delay of other pathophysiological processes. In addition, the pathological result of our study was supported by the biochemical analysis results. Even though no statistical difference was found, the AGE group showed better functional measurements than the control group. To explain more effects of AGE on SCI, further studies are needed.

In conclusion, our data suggest that AGE treatment protects the spinal tissue by decreasing MDA and increasing SOD levels. In addition, the pathological evaluation and the functional measurements supported these results. We have concluded that AGE may be useful in preventing secondary damage in experimental spinal cord trauma.

\section{REFERENCES}

1. Bareyre FM, Schwab ME. Inflammation, degeneration and regeneration in the injured spinal cord: insights from DNA microarrays. Trends Neurosci 2003;26:555-63.

2. Wang CY, Chen JK, Wu YT, Tsai MJ, Shyue SK, Yang CS, et al. Reduction in antioxidant enzyme expression and sustained inflammation enhance tissue damage in the subacute phase of spinal cord contusive injury. J Biomed Sci 2011;18:13.

3. Toklu HZ, Hakan T, Celik H, Biber N, Erzik C, Ogunc AV, et al. Neuroprotective effects of alpha-lipoic acid in experimental spinal cord injury in rats. J Spinal Cord Med 2010;33:4019.

4. Rajani Kanth V, Uma Maheswara Reddy P, Raju TN. Attenuation of streptozotocin-induced oxidative stress in hepatic and intestinal tissues of Wistar rat by methanolic-garlic extract. Acta Diabetol 2008;45:243-51.

5. Ashraf MZ, Hussain ME, Fahim M. Endothelium mediated vasorelaxant response of garlic in isolated rat aorta: role of nitric oxide. J Ethnopharmacol 2004;90:5-9.

6. Leung A, Foster S. Garlic. Encyclopedia of common natural ingredients. 2nd ed. New York: Wiley; 1995. p. 260-4.

7. Mathew BC, Daniel RS, Augusti KT. Hypolipidemic effect of garlic protein substituted for casein in diet of rats compared to those of garlic oil. Indian J Exp Biol 1996;34:337-40.
8. Cemil B, Topuz K, Demircan MN, Kurt G, Tun K, Kutlay $\mathrm{M}$, et al. Curcumin improves early functional results after experimental spinal cord injury. Acta Neurochir (Wien) 2010;152:1583-90.

9. Alkreathy H, Damanhouri ZA, Ahmed N, Slevin M, Ali SS, Osman AM. Aged garlic extract protects against doxorubicin-induced cardiotoxicity in rats. Food Chem Toxicol 2010;48:951-6.

10. Draper HH, Hadley M. Malondialdehyde determination as index of lipid peroxidation. Methods Enzymol 1990;186:42131 .

11. Sun Y, Oberley LW, Li Y. A simple method for clinical assay of superoxide dismutase. Clin Chem 1988;34:497-500.

12. Erol FS, Kaplan M, Tiftikci M, Yakar H, Ozercan I, Ilhan N, et al. Comparison of the effects of octreotide and melatonin in preventing nerve injury in rats with experimental spinal cord injury. J Clin Neurosci 2008;15:784-90.

13. Rivlin AS, Tator $\mathrm{CH}$. Effect of duration of acute spinal cord compression in a new acute cord injury model in the rat. Surg Neurol 1978;10:38-43.

14. Faden AI, Stoica B. Neuroprotection: challenges and opportunities. Arch Neurol 2007;64:794-800.

15. Baur JA, Sinclair DA. Therapeutic potential of resveratrol: the in vivo evidence. Nat Rev Drug Discov 2006;5:493-506.

16. Kalayci M, Coskun O, Cagavi F, Kanter M, Armutcu F, Gul $\mathrm{S}$, et al. Neuroprotective effects of ebselen on experimental spinal cord injury in rats. Neurochem Res 2005;30:403-10.

17. Carlson GD, Gorden C. Current developments in spinal cord injury research. Spine J 2002;2:116-28.

18. Emmez H, Börcek AÖ, Kaymaz M, Kaymaz F, Durdağ E, Civi S, et al. Neuroprotective effects of gabapentin in experimental spinal cord injury. World Neurosurg 2010;73:729-34.

19. Ferrari R, Ceconi C, Curello S, Cargnoni A, Alfieri O, Par$\operatorname{dini} \mathrm{A}$, et al. Oxygen free radicals and myocardial damage: protective role of thiol-containing agents. Am J Med 1991;91:95S-105S.

20. Block E. The chemistry of garlic and onions. Sci Am 1985;252:114-9

21. Borek C. Antioxidant health effects of aged garlic extract. J Nutr 2001;131:1010S-5S.

22. Moriguchi T, Saito H, Nishiyama N. Anti-ageing effect of aged garlic extract in the inbred brain atrophy mouse model. Clin Exp Pharmacol Physiol 1997;24:235-42.

23. Wei Z, Lau BHS. Garlic inhibits free radical generation and augments antioxidant enzyme activity in vascular endothelial cells. Nutr Res 1998;18:61-70.

24. Awazu S, Horie T. Antioxidants in garlic. II. Protection of heart mitochondria by garlic extract and diallyl polysulfide from the doxorubicininduced lipid peroxidation. In: Lanchance PP, editor. Nutraceuticals: Designer Foods III Garlic, Soy and Licorice; Food \& Nutrition Press, Trumbull, CT. 1997. p. 131-8.

25. Horie T, Awazu S, Itakura Y, Fuwa T. Identified diallyl polysulfides from an aged garlic extract which protects the membranes from lipid peroxidation. Planta Med 1992;58:468-9.

26. Gupta R, Singh M, Sharma A. Neuroprotective effect of antioxidants on ischaemia and reperfusion-induced cerebral injury. Pharmacol Res 2003;48:209-15.

27. Aguilera $\mathrm{P}$, Chánez-Cárdenas ME, Ortiz-Plata A, LeónAparicio D, Barrera D, Espinoza-Rojo M, et al. Aged garlic extract delays the appearance of infarct area in a cerebral ischemia model, an effect likely conditioned by the cellular antioxidant systems. Phytomedicine 2010;17:241-7. 